\title{
Assessment of Heavy Metal Pollution and Potential Ecological Risk in Soils of Tianjin Sewage Irrigation Region, North China
}

\author{
Beibei Hu, Jun Zhou, Lidong Liu, Weiqing Meng and Zuwei Wang*
}

College of Urban and Environment Science, Tianjin Normal University, Tianjin 300387, People's Republic of China

\begin{abstract}
The aim of the study was to investigate heavy metals concentrations in wheat field soils of Tianjin sewage irrigation region, and evaluate the potential ecological risk of heavy metals pollution. ICP-OES was employed to analyze the heavy metals concentrations in wheat field soils of Tianjin sewage-irrigation region. The grading standard of Tianjin soil environmental quality was used as the assessment foundation for soils and Lars Hakanson's potential ecological hazards index method was used to evaluate the heavy metals pollution potential ecological risk in soils. The results showed that: Cd concentrations in soils ranged from $0.03 \mathrm{mg} \cdot \mathrm{kg}^{-1}$ to $1.17 \mathrm{mg} \bullet \mathrm{kg}^{-1}$, with an average value of 0.46 $\mathrm{mg} \bullet \mathrm{kg}^{-1} ; \mathrm{Zn}$ concentrations in the soils ranged from $62 \mathrm{mg}^{\bullet} \mathrm{kg}^{-1}$ to $307 \mathrm{mg}^{\circ} \mathrm{kg}^{-1}$, with an average value of $129.08 \mathrm{mg}^{\bullet} \mathrm{kg}^{-1}$. The concentrations of $\mathrm{Cd}$ and $\mathrm{Zn}$ in the soils exceeded second grade standards of Tianjin soil environment quality, so the soil was polluted. The other heavy metal elements, such as $\mathrm{Cu}, \mathrm{Pb}, \mathrm{Cr}$ and $\mathrm{Ni}$, were all lower than second level of Tianjin soil environment quality standards, meaning that the soil was not contaminated by these heavy metals. The heavy metal concentrations were relatively rich in saline wet fluvo-aquic soil and clayification fluvo-aquic soil. Based on Lars Hakanson's potential ecological hazards index method, $\mathrm{Cd}$ had heavily ecological risk in soils and was the main pollutant, while the other heavy metals had lightly ecological risk. Ecological risk of total heavy metals pollution was moderate. The heavy metals were most likely from wastewater irrigation. The pollutants in the soils came mainly from sewage irrigation. The waste water treatment technology should involve steps to remove heavy metals causing risk to human health.
\end{abstract}

Keywords: Heavy metal pollution; Potential ecological risk; Pollution source; Soil; Tianjin sewage irrigation region

\section{Introduction}

Heavy metal is one of the important pollutants in the environment as a result of both natural and anthropogenic activities. Wastewater irrigation, solid waste disposal, sludge applications, vehicular exhaust and industrial activities are the major sources of soil contamination with heavy metals, and an increased heavy metal uptake by food crops grown on such contaminated soils is often observed. Wastewater irrigation is a widespread practice in the world and recently a number of articles have been published on wastewater-irrigated soils contaminated with heavy metals [1-11].

Heavy metals have a potential to contaminate soil, which can be dispersed and accumulated in plants and animals, and taken in by humans through consumption $[12,13]$. So heavy metals contamination has been a worldwide environmental concern with its potential ecological effect $[14,15]$. The present work deals with the quantification of heavy metal concentrations in soil and crops grown in Tianjin sewage irrigation region, the biggest sewage irrigation region in China which has 25-40 years sewage irrigation history. In earlier studies heavy metal concentrations were discussed [16-19] and the impact of heavy metals pollution on vegetables and crops was assessed [20-25]. While literature on the heavy metal pollution in wheat field soil of Tianjin sewage irrigation region was rare. Wheat is one of three main foods in north China and is main crop in Tianjin sewage irrigation region, so it is important to assess the potential ecological risk of heavy metals in wheat field soils in the study area for human health.

Soils of Tianjin Sewage Irrigation Region were examined with the following objectives: (1) to measure the concentrations of selected metals (i.e., $\mathrm{Cd}, \mathrm{Cu}, \mathrm{Pb}, \mathrm{Zn}, \mathrm{Cr}$ and $\mathrm{Ni}$ ) in soil; (2) to assess the potential ecological risk of heavy metals in soil; and (3) to identify pollution source of heavy metals in soil. The results of this research are needed for the government to control heavy metal pollution.

\section{Materials and Methods}

\section{Study area}

Tianjin wastewater irrigation region includes three main sewage discharge channel systems; they are North sewage discharge channel region, South sewage discharge channel region and Beijing sewage discharge channel region. The history of sewage irrigation was 25-40 years.

The North sewage discharge channel region is located in Dongli District with an irrigation region of $1.2 \times 104 \mathrm{hm}^{2}$. The South sewage discharge channel region is located in Xiqing District and Jinnan District with an irrigation region of $2.33 \times 104 \mathrm{hm}^{2}$. Beijing sewage discharge channel region in Tianjin is mainly located in Wuqing District and Beichen District, with an irrigation region of $3.87 \times 104$ $\mathrm{hm}^{2}$ in Wuqing District and $0.95 \times 104 \mathrm{hm}^{2}$ in Beichen District. Over the past four decades, human activities and prolonged use of irrigation water mixed with sewage have resulted in soil pollution with heavy metals of the study area [26].

The study area is located in the temperate zone continental climate, and the annual average temperature for the area is $11.4-12.9^{\circ} \mathrm{C}$ average

*Corresponding author: Zuwei Wang, College of Urban and Environment Science, Tianjin Normal University, Tianjin 300387, People's Republic of China, Tel: +8613512014515; E-mail: hubeibei0328@163.com

Received December 13, 2016; Accepted December 20, 2016; Published January 05, 2017

Citation: Hu B, Zhou J, Liu L, Meng W, Wang Z (2017) Assessment of Heavy Metal Pollution and Potential Ecological Risk in Soils of Tianjin Sewage Irrigation Region, North China. J Environ Anal Toxicol 7: 425. doi: 10.4172/21610525.1000425

Copyright: () $2017 \mathrm{Hu} \mathrm{B}$, et al. This is an open-access article distributed under the terms of the Creative Commons Attribution License, which permits unrestricted use, distribution, and reproduction in any medium, provided the original author and source are credited. 
Citation: Hu B, Zhou J, Liu L, Meng W, Wang Z (2017) Assessment of Heavy Metal Pollution and Potential Ecological Risk in Soils of Tianjin Sewage Irrigation Region, North China. J Environ Anal Toxicol 7: 425. doi: 10.4172/2161-0525.1000425

Page 2 of 6

annual precipitation $520-660 \mathrm{~mm}$ and the annual relative humidity in the range of $60 \%-80 \%$. Tianjin sewage irrigation region is plain terrain, where the soil types are mainly fluvaquents [27], which named as Ustochrepts by USA and Cambisols by UN. There are four types of fluvo-aquic soils in the study area, including ordinary fluvo-aquic soil, saline fluvo-aquic soil, wet fluvo-aquic soil and saline wet fluvo-aquic soil. Ordinary fluvo-aquic soil was main soil type. The main crops include winter wheat, summer corn and vegetables.

\section{Soil sampling and analysis}

Soil sampling: For this study, a total of 98 soil sampling sites were selected by using grid method (Figure 1). Using the quincunx distribution point method, each topsoil sample was collected from the plow layer $(0-20 \mathrm{~cm})$ at the central point and the four apexes of a $5 \mathrm{~km}$ $\times 5 \mathrm{~km}$ square. Approximately $1 \mathrm{~kg}$ of soil was collected, respectively, and then mixed, using the quartering method. All soil samples were air-dried, sieved to $<2 \mathrm{~mm}$, homogenized, and stored in Kraft paper envelopes prior to laboratory analysis and processing.

Soil samples analysis and quality control: Soil samples were analyzed for $\mathrm{pH}$ values, organic matter contents, total soil concentrations and the concentrations of main heavy metal pollutants, such as $\mathrm{Cd}, \mathrm{Cu}, \mathrm{Pb}, \mathrm{Zn}, \mathrm{Cr}$ and $\mathrm{Ni}$.

The soil $\mathrm{pH}$ values were measured by the voltammetric titrate method (PHs-10A) with a soil/water ratio of 1: 2.5 . The organic matter concentrations of soil were measured by the $\mathrm{K}_{2} \mathrm{Cr}_{2} \mathrm{O}_{7}$ method. The soil salinity was measured gravimetrically. For extraction of heavy metals such as $\mathrm{Cd}, \mathrm{Cu}, \mathrm{Pb}, \mathrm{Zn}$ and $\mathrm{Cr}$, one gram dried soil was digested in $15 \mathrm{ml}$ mixture of $\mathrm{HNO}_{3}, \mathrm{H}_{2} \mathrm{SO}_{4}$ and $\mathrm{HClO}_{4}(5: 1: 1)$ at $80^{\circ} \mathrm{C}$ until a transparent solution was obtained [28]. Water samples $(50 \mathrm{ml})$ were digested with $10 \mathrm{ml}$ of concentrated $\mathrm{HNO}_{3}$ at $80^{\circ} \mathrm{C}$ until the solution became transparent. These transparent solutions were then filtered through Whatman number 42 filter papers and diluted to $50 \mathrm{ml}$ with distilled water. The concentrations of $\mathrm{Cd}, \mathrm{Cu}, \mathrm{Pb}, \mathrm{Zn}$ and $\mathrm{Cr}$ in the filtrate were determined by using Inductively Coupled Plasma Optical Emission Spectrometry (ICP-OES, Leeman Labs, USA), fitted with a specific lamp of particular metal using appropriate drift blanks. The experiment was repeated three times.

The blank reagent and standard reference soil (from the National Research Center for Standards in China) were included in each sample batch to verify the accuracy and precision of the digestion procedure and subsequent analyses. Repeated analyses of standard samples were regularly carried out to control reproducibility.
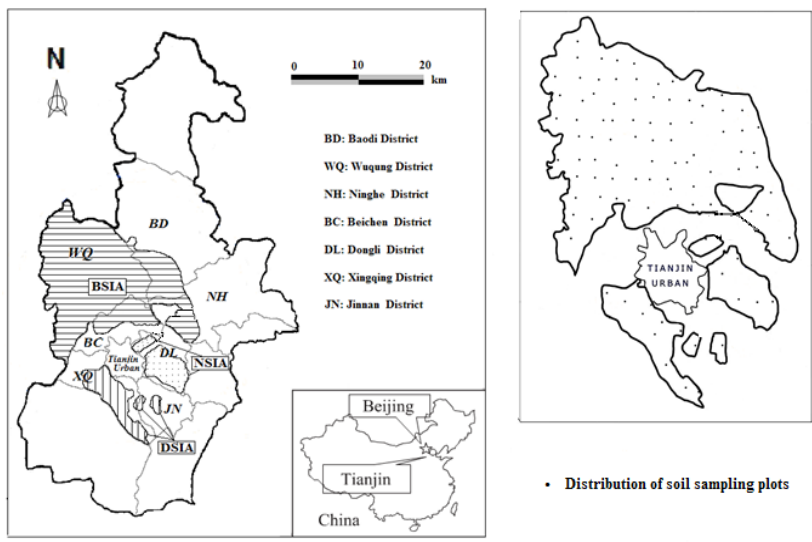

- Distribution of soil sampling plots

Figure 1: Location of study area and sampling sites.

\section{Contamination assessment methodology}

The potential ecological risk index method, which is based on the characteristics of a heavy metal and its environmental behavior, was advanced by the Swedish scholar Lars Hakanson [15,29-31], according to the characteristics of heavy metal and its environmental behaviour. The potential ecological risk index method is an approach to evaluate the heavy metal contamination from the perspective of sedimentology. It not only considers the heavy metal level in the soil, but also associates the ecological and environmental effects with toxicology and evaluates the pollution level using the comparable and equivalent property index grading method. The potential ecological risk index is related to the individual pollution coefficient, the heavy metal toxicity response coefficient, and the potential ecological risk individual coefficient, and is expressed as follows $[29,31]$.

$$
\boldsymbol{R}=\sum_{i=1}^{m} E_{r}^{i}=\sum_{i=1}^{m} T_{r}^{i} \cdot C_{f}^{i}=\sum_{i=1}^{m} T_{r}^{i} \frac{C^{i}}{C_{n}^{i}}
$$

Where $E_{r}^{i}$ is the potential ecological risk individual coefficient and $T_{f}^{i}$ is the toxicity response coefficient of a certain kind of metal toxicity using the standard heavy metal toxicity coefficient developed by Hakanson as a reference. The values for each element are in the order of $\mathrm{Zn}=1<\mathrm{Cr}=2<\mathrm{Cu}=\mathrm{Ni}=\mathrm{Pb}=5<\mathrm{As}=10<\mathrm{Cd}=30<\mathrm{Hg}=0$.

$C_{f}^{i}$ is the individual pollution coefficient, $C^{i}$ is the actual observed value of heavy metals in surface soil, and $C_{n}^{i}$ is a relative ratio, which is obtained from the background values of soil heavy metals in Tianjin. The detailed grading standard of heavy metal individual pollution coefficients and pollution ecological risk coefficients are listed in Table $1[29,31]$.

\section{Correlation analysis}

The correlation analysis was selected to identify pollution sources [32] and the data in this work were performed with SPSS 12.0 for Windows [33].

\section{Results and Discussion}

\section{Physicochemical properties and metal levels of soil}

The $\mathrm{pH}$ value in the upper layer soils ranged from 7.3 to 8.4 , with an average value of 7.62 , meaning that the soil was alkaline. The organic matter concentrations in the upper layer soils ranged from $0.80 \%$ to $2.7 \%$, with an average value of $1.47 \%$. The soil salinity in the upper layer soils ranged from $0.03 \%$ to $0.144 \%$, with an average value of $0.064 \%$, and part of the soils belonged to salinization soil.

The descriptive statistic of metal levels in upper horizon soils in Tianjin sewage irrigation region was summarized in Table 2. In addition, the environmental quality standards for soils of Tianjin were used as the reference values [34].

In general, the concentrations of heavy metals varied widely in the studied region. The mean contents of $\mathrm{Cd}$ and $\mathrm{Zn}$ in soils exceed the reference values. $89.8 \%$ of the soil samples exceeded obviously the second Grade standard of Cd in Tianjin soil environmental quality; further analysis showed that $75 \%$ of the soil samples exceeded the third Grade standard and 34.9\% exceeded the fourth Grade standard of Cd in Tianjin soil environmental quality, so the soil were moderately polluted by Cd. $46.94 \%$ of soil samples exceeded the second level of $\mathrm{Zn}$ in Tianjin soil environmental quality and $34.78 \%$ of soil samples exceeded the third level, so the soil had been lightly contaminated by $\mathrm{Zn}$. The average concentrations of $\mathrm{Cd}$ and $\mathrm{Zn}$ in soil from other studies $[18,19]$ were $0.24-1.86 \mathrm{mg} \cdot \mathrm{kg}^{-1}$ and $129-142 \mathrm{mg} \cdot \mathrm{kg}^{-1}$, which were similar 
Citation: Hu B, Zhou J, Liu L, Meng W, Wang Z (2017) Assessment of Heavy Metal Pollution and Potential Ecological Risk in Soils of Tianjin Sewage Irrigation Region, North China. J Environ Anal Toxicol 7: 425. doi: 10.4172/2161-0525.1000425

Page 3 of 6

\begin{tabular}{|c|c|c|c|}
\hline$E_{r}^{i}$ & $\begin{array}{c}\text { Grades of ecological risk of single } \\
\text { metal }\end{array}$ & $\boldsymbol{R}_{\boldsymbol{i}}$ & $\begin{array}{c}\text { Grades of potential ecological risk of the } \\
\text { environment }\end{array}$ \\
\hline$E_{r<40}^{i}$ & light & $\mathrm{R}_{\mathrm{i}}<150$ & light \\
\hline $40 \leq E_{r<80}^{i}$ & moderate & $150 \leq \mathrm{R}_{\mathrm{i}}<300$ & moderate \\
\hline $80 \leq E_{r<160}^{i}$ & heavy & $300 \leq \mathrm{R}_{\mathrm{i}}<600$ & heavy \\
\hline $160 \leq E_{r<320}^{i}$ & severe & $\mathrm{R}_{\mathrm{i}} \geq 600$ & severe \\
\hline $320 \geq E_{r}^{i}$ & Very severe & & \\
\hline
\end{tabular}

Table 1: Indices and grades of potential ecological risk of toxic metals contamination.

\begin{tabular}{|c|c|c|c|c|c|c|}
\hline Element & Cd & $\mathrm{Cu}$ & $\mathbf{P b}$ & $\mathrm{Zn}$ & $\mathrm{Cr}$ & $\mathrm{Ni}$ \\
\hline Ranges $\left(\mathrm{mg} \cdot \mathrm{kg}^{-1}\right)$ & $0.05-1.17$ & $10.92-61.32$ & $3.8-49.79$ & $62.22-333.6$ & $40.16-108$ & $15.91-61.42$ \\
\hline Average $\left(\mathrm{mg} \cdot \mathrm{kg}^{-1}\right)$ & 0.46 & 28.15 & 15.62 & 129.08 & 64.19 & 32.08 \\
\hline SD & 22.29 & 9.45 & 6.34 & 56.23 & 12.25 & 7.42 \\
\hline CV $(\%)$ & 48 & 33.58 & 40.57 & 43.57 & 19.09 & 23.14 \\
\hline Tianjin Standard- Class I a & $\leq 0.09$ & $\leq 28.35$ & $\leq 20.32$ & $\leq 76.27$ & $\leq 98.38$ & $\leq 32.39$ \\
\hline Tianjin Standard- Class II b & $\begin{aligned} & >0.09 \\
\leq & 0.159\end{aligned}$ & $\begin{array}{l}>28.35 \\
\leq 43.71\end{array}$ & $\begin{array}{l}>20.32 \\
\leq 32.83\end{array}$ & $\begin{array}{l}>76.27 \\
\leq 115.3\end{array}$ & $\begin{array}{l}>98.38 \\
\leq 107\end{array}$ & $\begin{array}{l}>32.39 \\
\leq 46.35\end{array}$ \\
\hline Tianjin Standard- Class III c & $\begin{array}{l}>0.159 \\
\leq 0.380\end{array}$ & $\begin{array}{c}>43.71 \\
\leq 70\end{array}$ & $\begin{array}{l}>32.83 \\
\leq 190\end{array}$ & $\begin{array}{l}>115.3 \\
\leq 190\end{array}$ & $\begin{array}{l}>107 \\
\leq 228\end{array}$ & $\begin{array}{c}>46.35 \\
\leq 53\end{array}$ \\
\hline Tianjin Standard- Class IV d & $\begin{array}{l}>0.380 \\
\leq 0.6\end{array}$ & $\begin{array}{l}>70 \\
\leq 100\end{array}$ & $\begin{array}{l}>190 \\
\leq 350\end{array}$ & $\begin{array}{l}>190 \\
\leq 300\end{array}$ & $\begin{array}{l}>228 \\
\leq 350\end{array}$ & $\begin{array}{l}>53 \\
\leq 60\end{array}$ \\
\hline Tianjin Standard- Class V e & $\begin{array}{l}>0.6 \\
\leq 1.0\end{array}$ & $\begin{array}{l}>100 \\
\leq 400\end{array}$ & $\begin{array}{l}>350 \\
\leq 500\end{array}$ & $\begin{array}{l}>300 \\
\leq 500\end{array}$ & $\begin{array}{l}>350 \\
\leq 400\end{array}$ & $\begin{aligned} & >60 \\
\leq & 200\end{aligned}$ \\
\hline Tianjin Standard- Class VI f & $>1.0$ & $>400$ & $>500$ & $>500$ & $>400$ & $>200$ \\
\hline
\end{tabular}

Note: a. Environmental quality standard for soils in Tianjin (Environmental Monitor Center of Tianjin, 1990), and numbers in class I are threshold levels of natural background value in Tianjin; b. Metal levels in class II are meaning the soil is clean. It is used as the soil assessment criterion; c. Metal levels in class III are meaning the soil is lightly polluted by heavy metals; d. Metal levels in class IV are meaning the soil is moderately polluted by heavy metals; e. Metal levels in class $V$ are meaning the soil is heavily polluted by heavy metals; f. Metal levels in class VI are meaning the soil is severely polluted by heavy metals.

Table 2: Descriptive statistics of metal levels in soils.

with this paper. It was implied that $\mathrm{Cd}$ and $\mathrm{Zn}$ may pose potentially unfavorable effects to crops and human health and the remarkable accumulation of them in soils indicated the significant anthropogenic inputs of pollutants.

The concentrations of $\mathrm{Cu}, \mathrm{Pb}, \mathrm{Cr}$ and $\mathrm{Ni}$ in most samples were lower than the second standard, and only six $\mathrm{Cu}$ soil samples and three $\mathrm{Pb}$ soil samples exceeded the second Grade standard, meaning that the soils were not contaminated by $\mathrm{Cu}, \mathrm{Pb}, \mathrm{Cr}$ and $\mathrm{Ni}$.

The concentrations of heavy metals are affected by physicochemical properties of the soils. Their correlation was shown in Table 3 .

Results showed that moderate correlation existed between the concentrations of heavy metals and the organic matters in the soil. So, the higher concentrations of organic matters of soil could lead to the bigger absorbance for heavy metals.

The order of the correlation between heavy metals and soil organic matters was $\mathrm{Cu}>\mathrm{Cr}>\mathrm{Pb}>\mathrm{Cd}>\mathrm{Ni}>\mathrm{Zn}$. The reason was that organic matters contained a large number of functions such as carboxyl, phenolic-based and alcohol-based groups, which could synthesize with heavy metals ions under certain conditions $[28,35,36]$.

There was a certain degree of positive correlation between heavy metals and soil salinities, and the order of the correlation was $\mathrm{Cr}>\mathrm{Cu}>\mathrm{Pb}>\mathrm{Zn}>\mathrm{Cd}>\mathrm{Ni}$. Other researcher got the same conclusions $[4,5]$.

In general, there was moderate correlation between $\mathrm{pH}$ values and the heavy metal contents of soils [1]. But in the study area, there was not. The reason might be that the soil was partial alkaline, and $\mathrm{pH}$ value ranged from 7.2 to 8.3 .

$\mathrm{Cd}$ and $\mathrm{Zn}$ were main pollutants. The concentration of $\mathrm{Cd}$ and $\mathrm{Zn}$ in different soil types was shown in Table 4. Additionally, the ordinary fluvo-aquic soil subgroup was selected to study the influence of soil texture, with a focus on sandy fluvo-aquic soil, loamy fluvo-aquic soil and clayey fluvo-aquic soil.

Results showed that there was the highest Cd concentration in the saline wet fluvo-aquic soil, followed by wet fluvo-aquic soil, saline fluvo-aquic soil and ordinary fluvo-aquic soil, respectively. It should be noted that the standard deviation of $\mathrm{Cd}$ was relatively small for 
Citation: Hu B, Zhou J, Liu L, Meng W, Wang Z (2017) Assessment of Heavy Metal Pollution and Potential Ecological Risk in Soils of Tianjin Sewage Irrigation Region, North China. J Environ Anal Toxicol 7: 425. doi: 10.4172/2161-0525.1000425

Page 4 of 6

\begin{tabular}{|c|c|c|c|c|c|c|}
\hline Soil property & Cd & $\mathrm{Cu}$ & $\mathrm{Pb}$ & Zn & $\mathrm{Cr}$ & $\mathbf{N i}$ \\
\hline Organic matter $\%$ & $0.3595^{* *}$ & $0.8109^{* *}$ & $0.5450^{* *}$ & $0.3159^{* *}$ & $0.5765^{\star *}$ & $0.3527^{* *}$ \\
\hline Salinity $\%$ & $0.2631^{*}$ & $0.4294^{* *}$ & $0.3958^{* *}$ & $0.2691^{* *}$ & $0.4370^{\star *}$ & 0.2018 \\
\hline $\mathrm{pH}$ value & -0.0930 & -0.1916 & -0.1653 & -0.1282 & $-0.2457^{\star}$ & 0.0882 \\
\hline
\end{tabular}

${ }^{* *}$ Correlation is significant at the 0.01 level; " Correlation is significant at the 0.05 level.

Table 3: Correlation between the concentrations of heavy metals and physicochemical properties of soils.

\begin{tabular}{|c|c|c|c|c|c|c|c|c|}
\hline & & \multicolumn{4}{|c|}{ Fluvo-aquic Soil Subgroup } & \multicolumn{3}{|c|}{ Fluvo-aquic Soil Texture } \\
\hline \multicolumn{2}{|c|}{ Soil Types } & Ordinary fluvo- & Saline fluvo-aquic & Wet fluvo-aquic & Saline wet fluvo- & Sandy fluvo-aquic & Loamy fluvo-aquic & Clayification \\
\hline \multirow{2}{*}{$\mathrm{Cd}$} & Range & $0.05-0.77$ & $0.12-0.97$ & $0.11-0.87$ & $0.28-1.17$ & $0.05-0.6$ & $0.05-0.65$ & $0.09-0.77$ \\
\hline & Average & 0.38 & 0.42 & 0.54 & 0.65 & 0.33 & 0.36 & 0.44 \\
\hline \multirow{2}{*}{$\mathrm{Zn}$} & Range & $62.22-333.6$ & 68.92-191.6 & $75.44-307.2$ & $78.14-232.9$ & $72.38-333.6$ & $75.01-255.8$ & $62.22-266.4$ \\
\hline & Average & 125.41 & 115.52 & 157.49 & 122.82 & 148.36 & 113.44 & 122.89 \\
\hline
\end{tabular}

Table 4: The concentrations of $\mathrm{Cd}$ and $\mathrm{Zn}$ in different types of soils $\left(\mathrm{mg} \cdot \mathrm{kg}^{-1}\right)$.

\begin{tabular}{|l|l|l|l|l|l|l|}
\hline \multicolumn{2}{|c|}{} & Cd & Cu & Pb & Zn & Cr \\
\hline \multirow{2}{*}{$E_{r}^{i}$} & Ranges & $16.67-323$ & $1.93-10.81$ & $0.94-12.25$ & $4.07-21.87$ & $0.43-1.09$ \\
\hline
\end{tabular}

Table 5: Potentially ecological risk assessment results of toxic metals in soils.

these four subgroups, which could indicate the Cd concentrations in the soils were correlation with the soil salinity.

The average concentration of $\mathrm{Zn}$ in the soils from highest to lowest was wet fluvo-aquic soil, ordinary fluvo-aquic soil, saline wet fluvoaquic soil and saline fluvo-aquic soil, which could indicate the $\mathrm{Zn}$ concentrations in the soils were low correlation with the soil salinity.

The concentrations of Cd showed an increasing trend with the content of clay minerals in the soil. The concentrations of $\mathrm{Zn}$ showed a decreasing trend with the content of clay minerals in the soil.

\section{Potential ecological risk assessment}

The ecological risk assessment results of toxic metals in soils were summarized in Table 5. It was found that the risk indices $\left(E_{r}^{i}\right)$ of metals were ranked in the following order: $\mathrm{Cd}>\mathrm{Zn}>\mathrm{Cu}>\mathrm{Pb}>\mathrm{Cr}$.

The average ecological risks of $\mathrm{Cd}$ in soils were above 80 , indicating that Cd posed a heavy risk to the local ecosystem. The values of $E_{r}^{i}$ for the other metals were below 40 , indicating light risk.

In order to quantify the overall potential ecological risk of observed metals in soils, the value of $R_{i}$ was calculated as the sum of the all five risk factors. It ranged from 24.04 to 369.02, with an average of 173.49, indicating the moderate potential ecological risk. The element of Cd accounted most of the total risks, and the average percentage was $89.68 \%$.

The result could be confirmed by other studies. The heavy metals pollution risk of vegetable field in Tianjin suburbs was evaluated based on Monto-Carlo model by Bin et al. and Shi et al. $[18,19]$, and the result showed that $\mathrm{Cd}$ accumulated in soil and vegetable. The source and enrichment of heavy metals in sewage-irrigated region soil of Dagu sewage discharge channel were discussed by Ref. [17]; it was found that the main pollutant in farmland field soil was Cd.

\section{Pollution source of heavy metals}

The correlation among heavy metals can be used to speculate their source. For investigation of inter-metal relationships in soils, correlation analysis was conducted, and the correlation matrix was shown in Table 6.

Results showed that positive correlation existed among $\mathrm{Cd}, \mathrm{Cu}$, $\mathrm{Pb}, \mathrm{Zn}, \mathrm{Cr}$ and $\mathrm{Ni}$ except the correlation between $\mathrm{Zn}$ and $\mathrm{Ni}$. $\mathrm{Zn}$ could enter into soils by fertilizer use [37]; so the correlation between $\mathrm{Zn}$ and other heavy metals was lower. The highly positive correlation among soil heavy metals suggested that these heavy metals had similar pollution sources. Therefore, the positive correlation among heavy metals in soils of the study area might indicate the combined soil pollution by multi-heavy metals as a result of the rapid development of industry and agriculture as well as human activities, especially sewage irrigation.

Source of heavy metals pollutants in soils could be determined by the study of heavy metals concentrations in soils by different irrigation types. There were four types of irrigation and the order of wastewater irrigation intensity was Wastewater irrigation>Clean water and wastewater mixed irrigation $>$ Intermittent wastewater irrigation $>$ Clean water irrigation. The order of heavy metals concentrations in soils by different irrigation types was similar (Figure 2). It might indicate that pollutants in the soils came mainly from sewage irrigation.

The concentrations of $\mathrm{Cd}$ and $\mathrm{Zn}$ in waste water was $0.6 \mathrm{mg} \cdot \mathrm{L}^{-1}$ and $0.19 \mathrm{mg} \cdot \mathrm{L}^{-1}$ separately [38], which was 2 times and 31 times as in the clean water, so they could reach higher concentrations after years of accumulation in soils.

\section{Conclusions}

$\mathrm{Cd}$ and $\mathrm{Zn}$ were the main pollutants of upper horizon soils in the Tianjin sewage irrigation region. However, the soils were not contaminated by other heavy metals, such as $\mathrm{Cu}, \mathrm{Pb}, \mathrm{Cr}$ and $\mathrm{Ni}$. Other researchers acquired the same results [17-19].

The concentrations of heavy metals in soils were influenced by the physicochemical properties of the soils. The organic matter 
Citation: Hu B, Zhou J, Liu L, Meng W, Wang Z (2017) Assessment of Heavy Metal Pollution and Potential Ecological Risk in Soils of Tianjin Sewage Irrigation Region, North China. J Environ Anal Toxicol 7: 425. doi: 10.4172/2161-0525.1000425

Page 5 of 6

\begin{tabular}{|c|c|c|c|c|c|c|}
\hline & Cd & $\mathrm{Cu}$ & $\mathbf{P b}$ & $\mathrm{Zn}$ & $\mathrm{Cr}$ & $\mathbf{N i}$ \\
\hline Cd & 1 & & & & & \\
\hline $\mathrm{Cu}$ & $0.5699^{* *}$ & 1 & & & & \\
\hline $\mathrm{Pb}$ & $0.4703^{* *}$ & $0.5873^{* *}$ & 1 & & & \\
\hline $\mathrm{Zn}$ & $0.3160^{* *}$ & $0.3121^{* *}$ & $0.2824^{* *}$ & 1 & & \\
\hline $\mathrm{Cr}$ & $0.6029^{* *}$ & $0.7811^{* *}$ & $0.4728^{* *}$ & $0.2841^{* *}$ & 1 & \\
\hline $\mathrm{Ni}$ & $0.5775^{\star \star}$ & $0.5545^{\star \star}$ & $0.3022^{* *}$ & 0.1840 & $0.6399^{* *}$ & 1 \\
\hline
\end{tabular}

"Correlation is significant at the 0.01 level

Table 6: Pearson correlation coefficients of metal contents in soils.

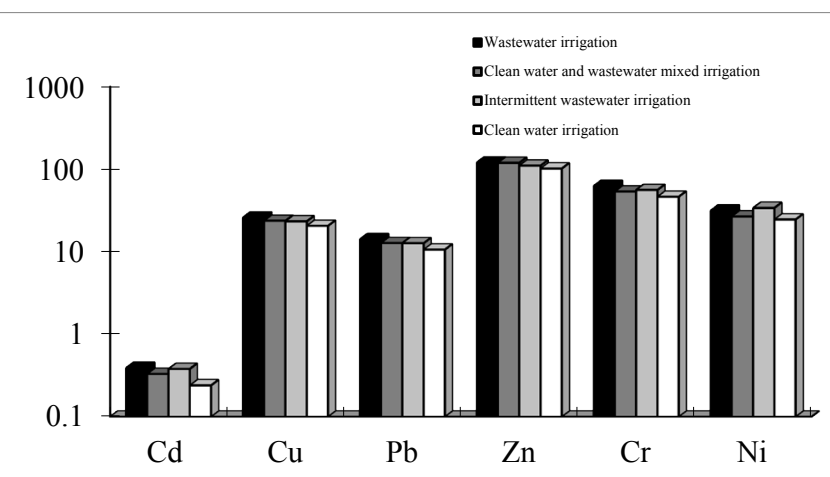

Figure 2: Heavy metals concentrations in soils by different wastewater irrigation intensity $\left(\mathrm{mg} \cdot \mathrm{kg}^{-1}\right)$.

concentrations and salinity of the soils might influence the heavy metal contents of soils $[4,5,28,35,36,39]$. The $\mathrm{pH}$ values of the soils were not correlated with heavy metals concentrations, most likely due to the partial alkalinity of the soils and the narrow $\mathrm{pH}$ ranges.

Types and textures of soils had an effect on the heavy metal concentrations and heavy metals were relatively enriched in saline wet fluvo-aquic soils and clayey fluvo-aquic soils. The ecological risk assessment results showed that Cd was the only metal posing a potentially heavy risk to environment while other heavy metals had lightly ecological risk. The overall risk indexes caused by the five toxic metals in soils samples were 173.9 , corresponding to moderate risk.

By means of comparison of metal concentrations and correlation analysis, the heavy metals came mainly from wastewater irrigation. Thereby, the control of pollution in wastewater is vital for the mitigation of toxic metal contamination in study area. Additionally, a well-managed waste disposal system is necessary to controlling over the moderate pollution caused by potentially toxic metals.

\section{References}

1. Barrow NJ, Whelan BR (1998) Comparing the effects of $\mathrm{pH}$ on the sorption of metals by soils and by goethite, and on uptake by plants. European Journal of Soil Science 49: 683-692.

2. Morera MT, Echeverría J, Garrido J (2002) Bioavailability of heavy metals in soils amended with sewage sludge. Canadian Journal of Soil Science 82: 433438.

3. Liu WH, Zhao JZ, Ouyang ZY Söderlund L, Liu GH (2005) Impacts of sewage irrigation on heavy metal distribution and contamination in Beijing, China. Environment International 31: 805-812.

4. Mapanda F, Mangwayana EN, Nyamangara J, Giller KE (2005) The effect of long-term irrigation using wastewater on heavy metal contents of soils under vegetables in Harare, Zimbabwe. Agriculture Ecosystem Environment 107: 151-165.

5. Rattan RK, Datta SP, Chhonkar PK, Suribabu K, Singh AK (2005) Long term impact of irrigation with sewage effluents on heavy metal content in soils, crops and groundwater-a case study. Agriculture Ecosystems Environment 109: 310-322.
6. Jamali MK, Kazi TG, Arain MB, Afridi HI, Jalbani N, et al. (2008) Effect of liming on the distribution of heavy metals in untreated industrial sewage sludge produced in Pakistan for the cultivation of Sorghum bicolor (L.). Environmentalist 28: 366-375.

7. Singh RP, Agrawal M (2008) Potential benefits and risks of land application of sewage sludge. Waste Manag 28: 347-358.

8. Marković M, Cupać S, Đurović R, Milinović J, Kljajić P (2010) Assessment of heavy metal and pesticide levels in soil and plant products from agricultural area of Belgrade, Serbia. Archives of Environmental Contamination Toxicology 58: $341-351$

9. Nogueira TA, Melo WJ, Fonseca IM, Marcussi SA, Melo GM, et al. (2010) Fractionation of $\mathrm{Zn}, \mathrm{Cd}$ and $\mathrm{Pb}$ in a tropical soil after nine-year sewage sludge applications. Pedosphere 20: 545-556.

10. Singh RP, Agrawal M (2010) Variations in heavy metal accumulation, growth and yield of rice plants grown at different sewage sludge amendment rates. Ecotoxicology and Environmental Safety 73: 632-641.

11. Chung BY, Song CH, Park BJ, Cho JY (2011) Heavy metals in brown rice (Oryza sativa L.) and soil after long-term irrigation of wastewater discharged from domestic sewage treatment plants. Pedosphere 21: 621-627.

12. Zhang Y, Zhang HW, Zhen-Cheng SU, Zhang CG (2008) Soil microbial characteristics under long-term heavy metal stress: A case study in Zhangshi Wastewater Irrigation Area, Shenyang. Pedosphere, 18: 1-10.

13. Wang B, Zhang Z (2012) The features and potential ecological risk assessment of soil heavy metals in Tianjin suburban farmland. Environmental Monitoring in China 28: 23-26

14. An YJ (2006) Assessment of comparative toxicities of lead and copper using plant assay. Chemosphere, 62: 1359-1365.

15. Liu J, Li Y, Zhang B, Cao J, Cao Z, et al. (2009) Ecological risk of heavy metals in sediments of the Luan River source water. Ecotoxicology 18: 748-758.

16. Mao JH, Lu WL (2001) Pollution status of Farmland soil in Tianjin and Countermeasures. Yunan Environmental Science S1: 96-98.

17. Wu GH, Su RX, Li WQ, Zheng HQ (2008) Source and enrichment of heavy metals in sewage-irrigated area soil of Dagu sewage discharge channel. Environmental Science 29: 1693-1698.

18. Wang B, Meng HT, Zhang Z (2010) The content features and potential ecological risk assessment of soil heavy metals in Tianjin suburban farmland. Environmental Study and Monitoring 4: 11-15.

19. Shi RG, Zhou QX, Liu FZ (2008) Cadmium accumulation and pollution risks to human health based on Monte-Carlo model of soil and vegetable-using vegetable field in Tianjin Suburbs as example. China Environmental Science 28: 634-639.

20. Pan J, Lu WL (1997) Pollution status of vegetable in suburb of Tianjin and Countermeasures. Agro-Environment and Development 4: 21-23.

21. Zheng HL, Zheng BW, Lu WL (2001) Effects of different sewage on soil heavy metals, crop yield and quality. Tianjin Agricultural Science 7: 17-21.

22. Zhai HQ (2010) Study on heavy metal pollution and safety in sewage irrigation regions of suburb in Tianjin. Tianjin University of Technology, Tianjin.

23. Wang Z, Zeng X, Geng M, Chen C, Cai J, et al. (2015) Health Risks of heavy metals uptake by crops grown in a Sewage Irrigation Area in China. Polish Journal of Environmental Studies 24: 1379-1386.

24. Zeng X, Wang Z, Wang J, Guo J, et al. (2015) Health risk assessment of heavy metals via dietary intake of wheat grown in Tianjin sewage irrigation area. Ecotoxicology 24: 2115-2124. 
Citation: Hu B, Zhou J, Liu L, Meng W, Wang Z (2017) Assessment of Heavy Metal Pollution and Potential Ecological Risk in Soils of Tianjin Sewage Irrigation Region, North China. J Environ Anal Toxicol 7: 425. doi: 10.4172/2161-0525.1000425

Page 6 of 6

25. Yu X, Wang Z, Lynn A, Cai J, Huangfu Y, et al. (2016) Heavy Metals in Wheat Grown in Sewage Irrigation: A Distribution and Prediction Model. Polish Journa of Environmental Studies 25: 413-419.

26. Li Q, Zhao Y, Chen Z, Qiao J (2010) Thallium in soil-cotton system in sewage irrigated soils of the North China Plain. Journal of Food Agriculture Environment 8: 899-903.

27. Soil Investigation Office of Tianjin (1990) Soil Species Records. Science and Technology Press of Tianjin. Tianjin.

28. Neal RH, Sposito G (1986) Effects of soluble organic matter and sewage sludge amendments on $\mathrm{Cd}$ sorption by soils at low $\mathrm{Cd}$ concentrations. Soil Science 142: 164-172.

29. Hakanson L (1980) An ecological risk index for aquatic pollution control. a sediment ecological approach. Water Research 14: 975-1001.

30. Ren HM, Liu JS, Yu JB, Zhang XL (2006) Distributions of Lead in urban soil and its potential risk in Shengyang city, China. Chinese Geographical Science 16: $127-132$

31. Lin J, Fu C, Zhang X, Xie K, Yu Z (2012) Heavy metal contamination in the water-level fluctuating zone of the Yangtze River within Wanzhou section, China. Biological Trace Element Research 145: 268-272.

32. Guo P, Xie ZL, Li J, Kang CL, Liu JH (2005) Relationships between fractionations of $\mathrm{Pb}, \mathrm{Cd}, \mathrm{Cu}, \mathrm{Zn}$ and $\mathrm{Ni}$ and soil properties in urban soils of Changchun, China. Chinese Geographical Science 15: 179-185.

33. Liao F, Zhou S, Zhang H, Wu S, Zhao Q (2008) Spatial distribution and changes of heavy metals of agricultural lands in typical pregrading coast in Dongtai City, Jiangsu province, China. Chinese Geographical Science 18: 276-283.

34. Environmental Monitor Center of Tianjin (1990) The Report for Environmental Background Values of Soil in Tianjin.

35. Basta NT, Tabatabai MA (1992) Effect of cropping systems on adsorption of metals by soils?. Single-metal adsorption. Soil Science 153: 108-114.

36. Adhikari T, Singh MV (2000) Cadmium sorption characteristics of major soils of Indian in relation to soil properties. Journal of the Indian Society of Soil Science 48: 757-762.

37. Wang ZW, Xu LM, Li ZJ (2002) The influence to trace elements contents in the soil environment in salt-alkaline wasteland reclamation and cultivation course Tianjin (glebe). Agro-environmental Protection 21: 77-78.

38. Environmental Monitor Center of Tianjin (1996) The Report for Environmenta Quality in Tianjin (1990-1995).

39. Wang Y, Qiao M, Liu Y, Zhu Y (2012) Health risk assessment of heavy metals in soils and vegetables from wastewater irrigated area, Beijing-Tianjin city cluster, China. Journal of Environmental Sciences 24: 690-698. 